\title{
Migration and foraging strategies at varying spatial scales in western North Atlantic right whales: a review of hypotheses
}

\author{
Robert D. KenneY*, Charles A. Mayo ${ }^{+}$AND Howard E. WinN ${ }^{\dagger 1}$ \\ Contacte-mail: rkenney@gso.uri.edu
}

\begin{abstract}
Western North Atlantic right whales (Eubalaena glacialis) utilise several important foraging habitats off the northeastern United States and eastern Canada, where they feed on dense patches of zooplankton. At a fundamental level, a right whale's optimal strategy should be to locate and exploit the prey patches with the highest net energetic return from foraging. There remain many questions, however, concerning their migration and foraging strategies and the environmental cues and sensory modalities involved in migration and foraging, all of which are likely to vary at different spatial scales. For example, a right whale most likely uses different mechanisms and strategies for location of primary feeding grounds than those used for detection of optimum prey patches within a feeding area. This paper proposes a multi-scaled, hierarchical, conceptual model of right whale migratory and foraging strategies and presents a variety of hypotheses concerning the mechanisms involved. Right whales may return to the general area of their feeding grounds based on prior experience. The locations of successful foraging in the immediately preceding years are likely to be re-visited, as are habitats to which an animal was exposed while accompanying its mother during its first year of life. It is also possible that the whales utilise large- or medium-scale environmental cues, such as currents, temperature discontinuities, or salinity signals indicating coastal plumes, to locate likely areas of high zooplankton patch density. Whilst on their feeding grounds, right whales tend to be aggregated, but there are usually outliers which may represent occasional excursions in search of other prey patches, though there is currently no evidence to address whether they communicate information about prey to other individuals. Their behaviour whilst actively feeding indicates that they can detect differences in patch density and adjust their behaviour accordingly. A likely sensory mechanism for quantification of patch density and triggering of feeding behaviour would be the vibrissae around the anterior opening of the mouth.
\end{abstract}

KEYWORDS: NORTH ATLANTIC RIGHT WHALE; BEHAVIOUR; HABITAT; FEEDING GROUNDS; PATCHES; ATLANTIC OCEAN; MIGRATION; MOVEMENTS; DISTRIBUTION; SITE FIDELITY

\section{INTRODUCTION}

Howard Winn developed a preliminary conceptual model of the annual migratory cycle of western North Atlantic right whales (Eubalaena glacialis) based on sightings data collected to that time (Winn and Price, 1982; 1983). The model was descriptive, partitioning the annual cycle into six phases: winter calving and breeding; late winter/early spring northward migration; spring feeding; early summer shift of feeding grounds; summer/autumn feeding; and autumn/early winter southward migration. The model did not specifically address either foraging strategies or the environmental cues and sensory mechanisms which right whales might use in their migrations and movements and in locating prey. The model was later incorporated into a broader description of western North Atlantic right whale distribution patterns (Winn et al., 1986), which similarly did not address migratory or foraging strategies.

The range of right whales in the western North Atlantic extends from the Gulf of Mexico to Iceland and Norway (Winn et al., 1986; Kraus et al., 1988; Gaskin, 1991; Knowlton et al., 1992; IWC, 2001), although the vast majority of sightings occur in continental shelf waters off the eastern United States and Canada, from Florida to Nova Scotia (Fig. 1). There are five important habitats in this range which have been consistently utilised by right whales on a seasonal basis, although they occur more-or-less regularly in other habitats and sometimes have exhibited marked departures from the general pattern described below.

(1) During the winter, right whales occur in nearshore waters off southeastern USA, along the coasts of Georgia and northeastern Florida (Winn et al., 1986;
Kraus and Kenney, 1991; Kraus et al., 1993). This habitat is apparently the principal or only calving ground for the population, and most of the animals sighted are adult females and mother/calf pairs. A small number of other animals, mostly juveniles, also occurs in this area. The winter habitat of the majority of the population remains undiscovered at this time.

(2) Right whales arrive in northeastern US waters in late winter in the relative shallows of Cape Cod Bay and Massachusetts Bay, with peak occurrence in these areas in March and April (Hamilton and Mayo, 1990; Kraus and Kenney, 1991). During 1986, and to a lesser degree in 1987, numbers of right whales remained in these waters through the summer and autumn (Mayo et al., 1988; Hamilton and Mayo, 1990; Payne, P. et al., 1990; Kraus and Kenney, 1991). In recent years there have been increased numbers of sightings in December and January (M.W. Brown, pers. comm.), but it is not clear whether these have resulted from a change in occurrence or increases in survey effort.

(3) Right whales are found in late spring and early summer, typically from April through June with a peak in May, in the Great South Channel region east of Cape Cod. This area is the primary spring feeding habitat for the majority of the western North Atlantic population (CETAP, 1982; Winn et al., 1986; Kraus et al., 1993; Kenney et al., 1995). The whales apparently abandoned this feeding ground in 1992; available data for 1993 and subsequent years have been sparse (Kenney, 2001).

(4) Right whales are found through the rest of the summer and into the autumn season in two feeding grounds in Canadian waters (Gaskin, 1987; 1991; Kraus et al.,

\footnotetext{
* University of Rhode Island, Graduate School of Oceanography, Bay Campus Box 41, Narragansett, RI 02882-1197, USA.

+ Center for Coastal Studies, P.O. Box 1036, Provincetown, MA 02657-1036, USA.

${ }^{\dagger}$ University of Rhode Island, Graduate School of Oceanography, Narragansett, RI 02882-1197, USA.

${ }^{1}$ See Acknowledgements.
} 


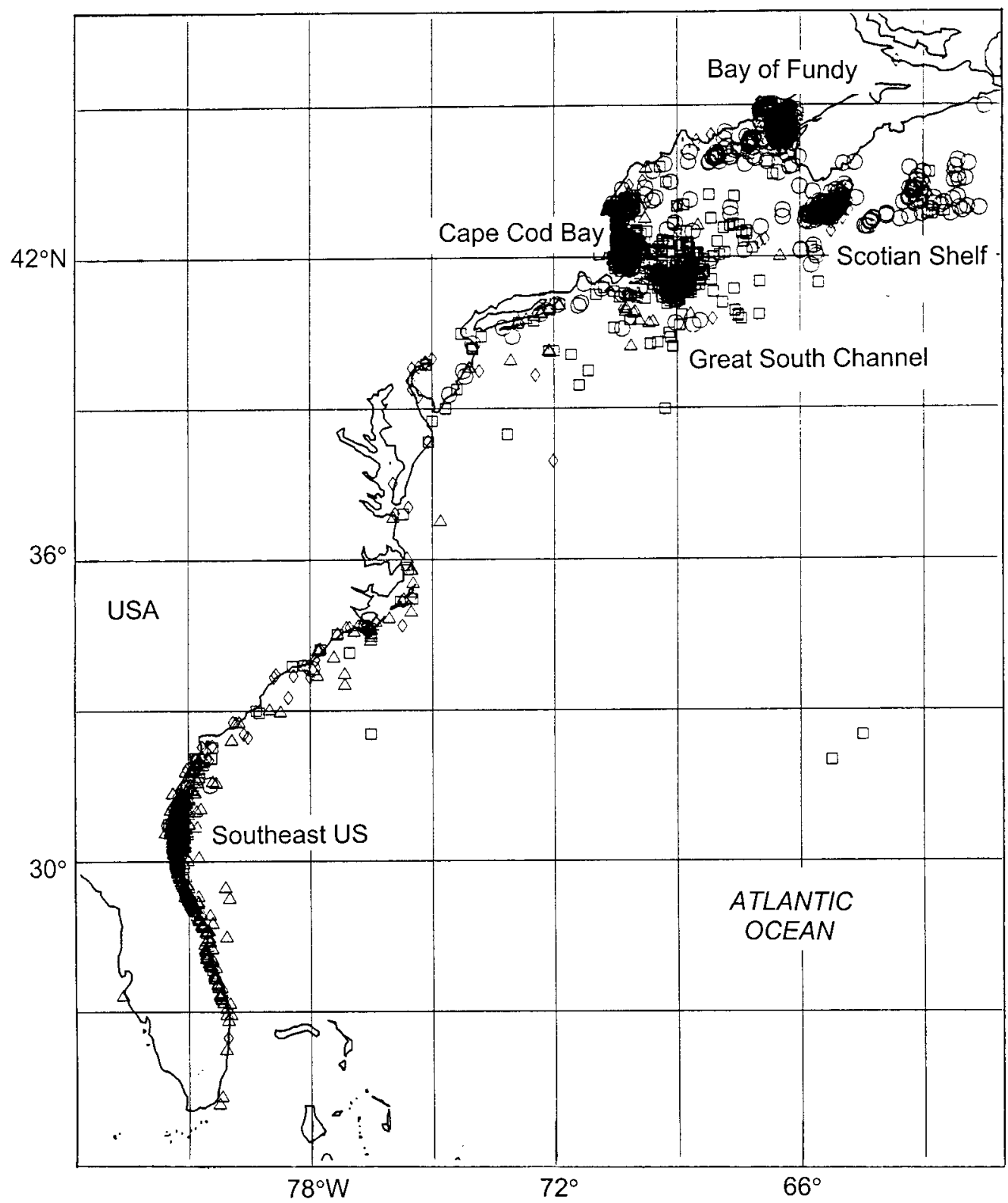

Fig. 1. Distribution of all western North Atlantic right whale sightings in the main range from Florida to Nova Scotia, through the end of 1997 ( $n=14,910$, with an additional 30 sightings beyond the boundaries of the map). Approximate seasons are differentiated by different symbols: $\Delta=$ January-March $(n=2,231)$; $\square=$ April-June $(n=2,137)$; O July-September $(n=9,346) ; \diamond=\operatorname{October-December~}(n=1,188)$.

1988; Murison and Gaskin, 1989). One portion of the population is found in the lower Bay of Fundy to the east of Grand Manan Island. The majority of summer/autumn sightings of mother/calf pairs occur here, although some females consistently take their calves to other unknown summer nursery habitat(s) (Schaeff et al., 1993; Malik et al., 1999).

(5) The second well-known summer/autumn habitat is the continental shelf waters off southern Nova Scotia, especially the Roseway Basin just north of Browns Bank, where mother/calf sightings are very rare (Kraus et al., 1988; Brown et al., 2001). Beginning in 1993, right whales apparently abandoned the Scotian Shelf and occupied the Bay of Fundy habitat in much higher numbers (Brown et al., 2001; IWC, 2001). The whales depart these Canadian habitats for their winter grounds in late autumn.

Other habitats which sometimes have significant numbers of right whales include Jeffreys Ledge in the western Gulf of
Maine, especially in autumn (Weinrich et al., 2000), and the edges of Georges Bank and some of the ledges and banks in the central Gulf of Maine (P.J. Clapham, pers. comm.).

All of the known right whale high-use habitats except for the winter habitat off southeastern USA are feeding grounds. Right whales feed on zooplankton, primarily copepods and especially large calanoid copepods such as Calanus (Matthews, 1938; Tomilin, 1957; Omura et al., 1969; Nemoto, 1970). A right whale's mass is ten or eleven orders of magnitude larger than that of its prey (an adult Calanus finmarchicus is approximately the size of a small grain of rice). Right whales are therefore very specialised and restricted in their habitat requirements - they must locate feeding areas where copepods are concentrated into high-density patches. Kenney et al. (1986) estimated that such zooplankton patches must reach concentrations on the order of tens to hundreds of thousands per cubic metre in order to obtain a long-term net energetic benefit from feeding. Copepod densities of that magnitude have rarely been measured in the North Atlantic, primarily because of 
limitations of sampling methodology (Brodie et al., 1978; Kenney et al., 1986; Wishner et al., 1988). Although the actual extent of such high-density zooplankton patches in the western North Atlantic is very poorly known, some of the highest densities have been measured near feeding right whales (Kenney et al., 1986; Murison and Gaskin, 1989; Mayo and Marx, 1990; Mayo and Goldman, 1992; Macaulay et al., 1995; Wishner et al., 1995; Beardsley et al., 1996).

It is clearly of interest to determine how right whales find their feeding grounds and, once there, how they locate dense zooplankton patches. This is true from both a general scientific and a management perspective. For example, it may provide insight into how and why right whales become entangled in fishing gear and how they may cope with potential changes in prey distribution caused by anthropogenic climate change. However, there are obvious methodological difficulties in studying the behavioural ecology of large whales. Under such circumstances, the formulation of plausible (but perhaps ultimately untestable) hypotheses has a role to play. Given the relatively extensive information on right whale distribution patterns and migratory timing along with some data on oceanographic conditions and zooplankton distribution on the feeding grounds, this paper reviews this information, along with foraging mechanisms and strategies for other species, and uses this to develop hypotheses for right whales.

The underlying assumption in this paper is that a right whale's optimal foraging strategy is to: (1) locate areas where high zooplankton patch density provides the maximal net return of energy relative to energy expended in foraging; and (2) remain there as long as the prey concentrations persist. An optimal strategy will also be to maximise time spent feeding and minimise time spent searching for or travelling between prey patches. Whilst it is probable that the strongest environmental cue for a foraging right whale will be the density of prey within small, exploitable patches in its immediate vicinity, it is unclear that the patches themselves will provide cues at any distance.

The objective of this paper is to expand on Winn's original model of the right whale annual cycle, incorporating hypotheses relative to the environmental cues, sensory modalities, and/or navigation mechanisms potentially utilised by migrating and foraging right whales. Given that there are few data on the sensory capabilities or mechanisms of large whales, it is inevitable that many of the hypotheses presented here are speculative. Despite this we will attempt to refine the speculations on whale migration presented by Norris (1967), with the benefit of three decades of additional research on large whales and especially other vertebrate species from which extrapolations may be informative. The intent is not to present an exhaustive review of the literature on sensory biology, but to provide enough references to give an interested reader an entry to the broader literature. One of the objectives here is to collate a range of hypotheses into a coherent conceptual framework which might then serve as a beginning for future research, a tool for beginning to address questions of critical management importance and a target for constructive criticism.

\section{MODEL AND HYPOTHESES}

The suite of strategies utilised by right whales in locating feeding grounds and prey concentrations undoubtedly varies with the spatio-temporal scale involved - from long-distance seasonal migrations over weeks or months down to minute-by-minute selection of the optimal prey patches within a particular feeding area. The strategy of this paper is to similarly begin from the largest scale and work down to the smallest.

\section{Basin scale - 1000's of kilometres}

Question: How do right whales navigate during their long-distance migrations between their wintering grounds and their feeding grounds in the Gulf of Maine region, and between feeding grounds?

The distribution of all right whale sightings to date largely confirms the general pattern described by Winn (Winn and Price, 1982; Winn et al., 1986; Fig. 1) of a north-south feeding/calving migration typical of mysticetes (Norris, 1967). As the intensity of sampling effort increases, the number of sightings in areas and seasons outside of the core habitats/seasons has been increasing. Additionally, there have been observed anomalies in the distribution patterns, such as the abandonment of the Great South Channel in 1992 and of the Roseway Basin beginning in 1993.

The location of winter grounds for most of the population is still not known. It is possible that there is no specific winter ground, and that the animals are broadly dispersed. It is also possible that some individuals, perhaps even significant numbers, winter within the range of habitats described as spring-summer-autumn feeding grounds and that they have been missed due to a combination of dispersed and inconsistent distribution, inadequate survey coverage and generally poorer weather and sightability.

The navigation mechanisms used at this scale are probably more related to geography than to prey distributions. There are a number of potential mechanisms which might be used as discussed below.

\section{(1) Topography}

Right whales might simply follow the topography, such as the coastline, continental shelf break, particular isobaths, or undersea landmarks such as seamounts. Knowlton (1997) concluded that the majority of recent right whale sightings off the USA mid-Atlantic were relatively nearshore. Historically, there were shore-based right whale fisheries on the Outer Banks of North Carolina and at eastern Long Island, New York (Reeves and Mitchell, 1986; 1988). Homing pigeons (Columba livia) appear to use visual landmarks within the vicinity of their home loft (Berthold, 1996). The use of landmarks, learning and memory is believed to be common in terrestrial mammals, particularly in movements within a home range (Bovet, 1992). Pike (1962) concluded that gray whale (Eschrichtius robustus) movements from headland to headland along the west coast of North America were evidence for migration via landmarks. Norris (1967) speculated that migrating mysticetes could follow a given depth contour, or use consistent sound sources as acoustic 'landmarks'. He also hypothesised that low-frequency sounds produced by mysticetes could be used for coarse-scale echolocation during migration, perhaps by measuring water depth or imaging large topographic features. Ellison et al. (1987) similarly suggested that bowhead whales used reverberation from their vocalisations to detect leads in the pack ice.

\section{(2) Sun}

Right whales might use the sun as a compass cue. Sun-compass orientation is well-known in birds (Berthold, 1996) and has also been shown in fishes (Quinn and Dittman, 1992; Dittman and Quinn, 1996) and small mammals 
(Bovet, 1992). Pilleri and Knuckey (1969) concluded that common dolphins (Delphinus delphis) in the Mediterranean used solar cues.

\section{(3) Magnetism}

Right whales might utilise the Earth's magnetic field for migratory cues, either as a compass mechanism or as a geomagnetic map system. In some areas, at least, studies have correlated cetacean stranding patterns with geomagnetic anomalies (Klinowska, 1985; 1990; Kirschvink et al., 1986; Kirschvink, 1990), suggesting that cetaceans possess some type of magnetic sense. Walker et al. (1992) suggested that fin whales in the western North Atlantic utilised geomagnetic anomaly patterns as cues during their migrations; these magnetic 'stripes' on the seafloor trend north-south in the Atlantic basin (Gross, 1996) and thus may serve as ideal cues for north-south migrating mysticetes. There is good evidence that hatchling loggerhead sea turtles (Caretta caretta) are capable of detecting the geomagnetic field and using it as a compass, as well as evidence that geomagnetic cues might also be used as a bi-coordinate map (Lohmann and Lohmann, 1996). Use of a geomagnetic compass is also documented or hypothesised in migrating and homing birds (Wiltschko and Wiltschko, 1996), sharks (Kalmijn, 1982), salmon (Dittman and Quinn, 1996), tuna (Walker, 1984), amphibians (Sinsch, 1992) and rodents (Bovet, 1992). One potential mechanism for magnetoreception is possession of magnetite particles in the brain, which have been detected in common dolphins (Zoeger et al., 1981) and humpback whales (Megaptera novaeangliae) (Fuller et al., 1985). However, Gerrits and Kastelein (1990) have proposed a neural mechanism for magnetoreception in cetaceans which does not involve magnetite.

\section{(4) Sounds}

Right whales and other mysticetes are probably capable of hearing and localising the direction of very low-frequency sounds (Ketten, 1991; Richardson, 1995) and transmission distance of sound in water is inverse to frequency (Malme, 1995). Consistent sources of these infra-sounds (e.g. surf zones along the coast, zones of seismicity along the mid-ocean ridge) might be useful as an acoustic 'map' of a region, as suggested by Norris (1967) for more typical acoustic sources. Infra-sound has been hypothesised to be used for geographic location cues by homing pigeons, which are capable of hearing sounds below $20 \mathrm{~Hz}$, and other birds (Berthold, 1996).

\section{(5) Ocean currents}

Right whales might use ocean current patterns, either for directional cues or for a locomotory assist in one or both directions. Hatchling sea turtles from the eastern USA are believed to follow the Gulf Stream/North Atlantic gyre system to developmental habitats in the eastern North Atlantic (Carr, 1980; 1982; 1987; Hamner, 1988). Norris (1967) suggested that "currents or water masses might serve as guideposts' for migrating whales. Although Winn et al. (1986) suggested that northward-migrating right whales in the spring could save energy by following the Gulf Stream for some part of the way, there have been no sightings of right whales in Gulf Stream waters and most northbound migrants which have been observed have been relatively close to shore (Knowlton, 1997).

\section{Regional scale - 10's to 100's of kilometres}

Question: Once a right whale arrives in the vicinity of the Gulf of Maine from its wintering habitat, how does it find the location of feeding grounds?

The primary hypothesis considered is that right whales return to particular feeding grounds based largely on prior experience i.e. that learning is important. If so, it seems probable that there may be a hierarchy of preferred areas. For example, one could envisage a situation where the location of successful foraging in the previous year is ranked highest, with previous years' locations ranked lower.

Under such an hypothesis, matrilineal learning is probably important, as has been shown for feeding site fidelity in humpbacks (Baker et al., 1986; 1990; Clapham and Mayo, 1990; Clapham et al., 1993). Both resighting and genetic data support the hypothesis of maternally directed habitat fidelity in western North Atlantic right whales (Malik et al., 1999; Brown et al., 2001). A female right whale accompanied by a calf was tracked via a satellite-monitored radio tag in August-October 1990 (Mate et al., 1997). The pair moved from the Bay of Fundy to Massachusetts Bay, then southward to near New Jersey, and finally back to Massachusetts Bay, a minimum distance of at least $3,833 \mathrm{~km}$ in 41 days. This suggests that at least some mothers with calves range widely and visit several potential feeding grounds.

Satellite tag studies (Mate et al., 1997) have also shown that individuals can make occasional excursions over long distances, possibly in search of alternate feeding areas. This suggests the possibility for communication of foraging information between individuals, though direct evidence for this is lacking. Although Watkins and Schevill (1976) found that feeding right whales rarely vocalised, the possibility of communication between individuals with respect to foraging areas cannot be ruled out.

Norris (1967) hypothesised that another environmental cue which whales could utilise to locate feeding areas within a general region might be water mass characteristics, which could include temperature, currents, salinity, stratification, and chemistry. One cue which migrating right whales might use to locate the Gulf of Maine from offshore south of New England might be the spring run-off plume (with reduced salinity and containing organic compounds which originate in freshwater systems) that exits the Gulf via the Great South Channel (Chen et al., 1995a). Mysticetes are believed to possess a limited olfactory sense (Anderson, 1969; Pilleri and Gihr, 1970; Berta and Sumich, 1999; Wartzok and Ketten, 1999) but it would probably not be useful at this spatial scale. However, cetaceans do possess gustatory (taste) and other intra-oral chemoreceptors which might be useful in this regard (Nachtigall, 1986; Kuznetzov, 1990; Pryor, 1990; Wartzok and Ketten, 1999). Sorensen (1986) showed that migrating elvers of the American eel, Anguilla rostrata (entering freshwater systems for the first time after hatching in mid-ocean), are attracted to organic compounds produced via microbial breakdown of plant detritus; such compounds are a generic signature of freshwater run-off from terrestrial sources. Raymond M. Gilmore (pers. comm., cited by Norris, 1967) believed that gray whales located the entrances to their breeding lagoons in Mexico by 'tasting' the water. Interestingly, in the spring of 1998 the largest numbers of right whales in recent memory were seen off Rhode Island, with 23 individuals sighted $25-30 \mathrm{~km}$ south of the entrance to Narragansett Bay on 19 April (P. Gerrior, pers. comm.). Although it may have been entirely coincidental, this occurrence of right whales followed a 
period of heavy rains. If migrating right whales moving north and east over or beyond the continental shelf use the spring run-off plume exiting the Great South Channel as their cue to 'turn left' into the Gulf of Maine, the heavy rainfall in Rhode Island may have simply supplied the cue early.

\section{Mesoscale - 1 to 10 kilometres}

Question: Once in the general area of their Gulf of Maine feeding grounds, how do right whales locate zooplankton concentration areas?

A number of studies have shown that dense Calanus concentrations in the Great South Channel occur in areas of convergence near a persistent tidal mixing front which separates water masses of differing temperature, salinity and biological properties (CETAP, 1982; Wishner et al., 1988; 1995; Brown, C.W. and Winn, 1989; Macaulay et al., 1995; Beardsley et al., 1996). A similar phenomenon appears to occur in right whale feeding grounds in Nova Scotian waters (Murison and Gaskin, 1989). Other similar oceanic discontinuities may also be locations of zooplankton concentration - in September 1990, a satellite-tagged adult male right whale made an extensive excursion beyond the continental shelf along the eastern edge of an anti-cyclonic warm-core ring, where an entrained plume of cooler shelf water was located (Mate et al., 1997).

At this scale, several of the mechanisms proposed at greater distances will no longer be of value; it is difficult to see how compass orientation mechanisms could prove useful, for example. It is also unlikely that copepod patches produce significant far-field detection cues, although predators aggregating to exploit zooplankton concentrations (e.g. fish schools and flocks of seabirds) might produce enough sound to be detected at some distance. Chemosensory cues by contrast might be useful indicators. Salinity or other water mass properties might indicate the location of appropriate conditions for the development of dense copepod patches, whilst organic compounds produced by zooplankton may even be direct indicators of dense patches. An alternative hypothesis to that given above for the spring 1998 occurrence of right whales in Rhode Island Sound is that the whales detected the presence of zooplankton concentrations directly. They then remained in the area for about two weeks feeding on concentrations of zooplankton that the local fishermen characterised as unusual (another alternative is that they accidentally came across a suitable prey patch while moving through the region, and stayed until the patch was depleted or dispersed). Any chemical cues from zooplankton would probably be detected by the gustatory sense. Humans are sometimes able to smell patches of zooplankton-rich productive water, therefore right whales might also detect such airborne chemical cues. However, localisation of the source of such odours also requires the ability to detect wind direction. Procellariiform seabirds (petrels, albatrosses, shearwaters and storm petrels) have been shown to use olfaction to return to their nests at night and to locate prey; after detecting an odour they fly upwind to locate the source (Wenzel, 1980).

Temperature cues might also be useful indicators. In the Great South Channel the Calanus patches that right whales feed upon are typically located north of the tidal mixing front, in a water mass which is stratified with a warmer surface layer (Wishner et al., 1988; 1995; Brown, C.W. and Winn, 1989; Chen et al., 1995b). South of the front, in shallower water, the water column is completely mixed by strong tidal currents and is colder at the surface. A right whale might detect water temperature using sensors which could be either cutaneous or intra-oral.

At this scale, right whales are highly aggregated, often with several tens of animals within a radius of a few kilometres (Kraus et al., 1988; Murison and Gaskin, 1989; Kenney et al., 1995). However, there are frequently scattered individuals located well beyond the main aggregations. As has been suggested earlier, one possibility is that these may be 'scouts,' searching for other prey patches. Alternatively, they might be poorer competitors who are forced into suboptimal habitats (perhaps younger individuals). Hain et al. (1995) noted that the Gulf of Maine humpback whales which they observed with pronounced wounds on the sides of one or both jaws, attributed to abrasions incurred from contact with the sea bottom during feeding, were largely juveniles, possibly forced by intra-specific competition into a suboptimal foraging strategy.

\section{Microscale - centimetres to 10's of metres}

Question: Within a feeding ground, how do right whales detect the optimal (i.e. densest) zooplankton patches?

A foraging right whale should feed in the patch or layer of zooplankton which provides the maximum net energy benefit, i.e. the highest return relative to energy expended in foraging. For example, feeding right whales in the western North Atlantic typically swim at 1-3 knots $(2-6 \mathrm{~km} / \mathrm{hr})$ (Watkins and Schevill, 1976; 1979; Mayo and Marx, 1990), while Hamner et al. (1988) observed a southern right whale (E. australis) feeding on Antarctic krill (Euphausia superba) while swimming at 8-9 knots $(15-17 \mathrm{~km} / \mathrm{hr})$. A whale with a choice of feeding on a copepod patch of lower caloric concentration or a richer krill patch would get a better return from the copepods if it had to swim much faster (with the resulting increased cost of locomotion) in order to overcome the avoidance response of the stronger-swimming krill. An optimally foraging whale ought to be able to quantify at least the abundance of zooplankters within small-scale patches, and ideally their individual masses and size distribution, and consequently biomass or energy density. The behaviour of feeding right whales suggests that they are capable of detecting fine-scale variations in zooplankton density in both the horizontal and vertical dimensions and adjusting their behaviour accordingly. In the horizontal dimension, the path of a feeding whale is typically sinuous, with many turns, as it apparently attempts to remain within the area of maximum copepod density (Mayo and Marx, 1990). Turns in apparent response to changes in the fine-scale horizontal distribution of zooplankton are most easily observed at the margins of surface patches (Mayo and Marx, 1990). In the vertical dimension, Mayo and Goldman (1992) reported that whales feeding on zooplankton layers in the upper $2 \mathrm{~m}$ of the water column regularly adjusted their swimming depth, apparently in response to changes in the depth of the most dense parts of the layer. Simultaneously-collected zooplankton data demonstrated that vertical adjustments of as little as $20 \mathrm{~cm}$ could increase the whale's energy intake by as much as $20 \%$ above that predicted if the animal simply swam at a constant depth.

Visual cues may be used by whales skim-feeding during daylight hours at the surface or in the near-surface layer - a whale might simply see the thickest zooplankton layer or some manifestation of it (e.g. shadowing). However, visual cues are probably less useful when feeding at depth as occurs most often in the Great South Channel (Kenney et al., 1995; Winn et al., 1995) and Bay of Fundy (Murison and Gaskin, 
1989; Goodyear, 1993) or when feeding at night. One interesting possibility is that right whales might be able to detect dense zooplankton layers at depth or in total darkness if there are significant numbers of bioluminescent individuals, e.g. the copepod Metridia lucens.

Waterborne chemical signals given off by zooplankton aggregations may be useful cues, although their utility will be a complex function of chemical persistence, turbulence and rate of diffusion or dispersal. A substance with a long persistence might be less useful as an immediate indicator of zooplankton concentration; however, very short persistence times or rapid dispersal would also reduce the value of a chemical cue. If the sensory receptors for chemical cues are in the mouth, detecting such cues might entail a significant energetic cost if it required frequent mouth opening and subsequent increases in drag, unless the whale is capable of 'sampling' by drawing in small volumes of water without opening the mouth significantly. Airborne chemical cues may also be detectable, but are probably less useful to whales, as discussed above.

Tactile cues are probably the most reliable indicator of zooplankton density at this scale. A right whale could utilise the sinus hairs ('vibrissae') on its head for detection of individual zooplankton organisms. The vibrissae are concentrated near the front of the mouth opening; Payne (1976) includes an excellent photograph which clearly shows the vibrissae on the tip of the rostrum and chin of a southern right whale. Cetacean vibrissae are richly enervated and appear to be sensitive tactile organs (Ling, 1977). An individual zooplankter contacting one of the vibrissae as the whale is swimming forward will deflect the hair to some degree. The frequency of deflections will be a measure of zooplankton density, while the magnitude of each hair deflection is a measure of the mass of an individual zooplankter. Summation of the two would be an indication of biomass density, possibly triggering open-mouth feeding when a threshold is reached. Differential signals from vibrissae in separate locations would cue the whale to adjust its mouth opening up/down or left/right. However, the system may be even simpler, based only on organism density, not biomass density. Comparison of small-volume zooplankton samples taken in Cape Cod Bay as near as possible to the mouth of feeding right whales with those collected near non-feeding whales and where no whales are present suggests that concentrations of approximately $4,000 \mathrm{~m}^{-3}$ represent the threshold for releasing open-mouth feeding behaviour, but that the size of the zooplankters which are present has little effect on the threshold (Mayo and Goldman, 1992; unpublished data). Gustatory and/or intra-oral tactile cues may be the final indication of prey patch suitability. Right whales in Cape Cod Bay are occasionally observed to feed on dense patches of cyprids (the free-swimming larvae of barnacles), but those feeding bouts end very quickly, perhaps because the small size of the cyprids means they are not filtered very effectively and therefore do not provide the whale with the feedback cue(s) indicating successful feeding.

\section{DISCUSSION}

This paper represents a first attempt to construct a conceptual model of the mechanisms and strategies that may be involved in the annual cycle of distribution, migration, movements and foraging of western North Atlantic right whales. A nested framework of hypotheses is given, some testable and some probably not, spanning a range of spatial and temporal scales. Four different spatial scales were considered and it is very likely that multiple redundant mechanisms operate at each of them. At two of the scales, basin scale and mesoscale, the available information is not sufficient to conclude that any particular mechanism is more likely than any other. At the regional scale, the concordance of resighting, genetic and habitat use data lead to the conclusion that prior experience, learning and habitat philopatry comprise the principal mechanism. At the microscale, the use of the tactile sense, mediated via the vibrissae, is most consistent with observed foraging behaviour. With the possible exception of long distance seasonal migrations, it is presumed that feeding is the principal underlying drive. It is certain that there are other factors which drive a right whale's decision making (e.g. reproduction and social considerations) however, for the most part these are not considered here. There may also be additional unknown factors.

It is proposed that the movements of right whales in western North Atlantic continental shelf waters reflect adaptive responses to the distribution of prey at many scales. It is advantageous for whales to locate and forage in those areas which return the greatest energy value to them. Because zooplankton productivity and exploitability can vary at many temporal and spatial scales, some flexibility in the responsiveness of right whales to environmental variability should be expected. If it is to be adaptive, the life history of a species which moves and forages over large, variable, and at times, unpredictable marine habitats should incorporate a wide range of sensory capabilities, as well as a capacity for appropriate decision-making. The responses of right whales to variability in prey result in distribution patterns that will vary from minutes to decades and from metres to hundreds of kilometres. It is likely that the unexpected changes in right whale distribution which have been observed in the last decade (which may be 'anomalous' only within the limited time scale of our observations) are examples of right whales responding to variation in the distribution and quality of zooplankton resources, about which little is understood. However, there is certainly a limit to the effectiveness of adaptive responses to environmental change for any species, and there are very likely levels or rates of changes to which right whales will have difficulty responding. Broad regional changes in zooplankton productivity, or wide-scale alterations in hydrography which shift the locations of optimum zooplankton-aggregating conditions, might be expected to profoundly impact a population which would otherwise be capable of successfully responding to more local and/or short-term changes in their prey.

There is much that remains unknown about the migratory and foraging strategies of right whales and other mysticetes. This paper has attempted to set forth a series of hypotheses concerning these strategies. However it is accomplished and however unlikely it may be that we will completely understand the mechanisms involved, it is clear that right whales are capable of detecting the dense patches of zooplankton which constitute their preferred prey resource. The highest measured copepod densities in the western North Atlantic have been in right whale feeding grounds, dating back at least to Henry Bigelow's (1926) report of extremely high summer densities of Calanus finmarchicus on the Nova Scotian shelf near Browns Bank. However, questions relative to the possibility that right whales may at times have difficulty in locating sufficient food, and hence be energy-limited, may be critically important in managing the recovery of the western North Atlantic population. 
The annual rate of increase in the abundance of western North Atlantic right whales until 1992 was estimated at 2.5\% (Knowlton et al., 1994), substantially lower than the rates observed in Southern Hemisphere populations (Best and Underhill, 1990; Payne, R. et al., 1990). Since 1992, the trend has reversed to a decline (Caswell et al., 1999; IWC, 2001; Kraus et al., 2001) and inter-birth intervals have lengthened significantly (Kraus et al., 2001); the continued survival of the population is now in question (Caswell et al., 1999; IWC, 2001). The shift from population growth to decline coincided with significant changes in distribution such as the abandonment of the Great South Channel in 1992 (Kenney, 2001) and the Scotian Shelf beginning in 1993 (Brown et al., 2001; IWC, 2001). At the same time, there is evidence of thinner blubber layers in North Atlantic animals (Moore et al., 2001). All of this is strongly suggestive that the availability or distribution of prey changed, and that the whales have been unable to locate alternative feeding grounds which are sufficient to completely supply their energetic needs.

The present abundance of the western North Atlantic population is estimated at about 300 animals (IWC, 2001; Kraus et al., 2001). The historical abundance is poorly known; the early North Atlantic whaling which depleted the population (Aguilar, 1986) left behind only a sparsely written catch record (Reeves et al., 1992). It is sometimes assumed, however (e.g. in the USA right whale recovery plan - NMFS, 1991), that the original population was around 10,000 or more. The present population is therefore far below carrying capacity (assuming there has not been a drastic alteration in the availability of zooplankton and/or abundance of competitors in the last several hundred years), and the whales should be relatively immune to any effects of intra-specific competition for resources. However, observed statistical correlations between reproduction and global atmospheric cycles (Kenney, 1998 and unpublished) and the increase in calving intervals corresponding in time to marked distributional shifts (Kraus et al., 2001) suggests that they are sensitive to oceanographic changes acting through prey availability. If a better understanding of how right whales locate their feeding grounds is achieved, it might be easier to understand these phenomena and to predict future changes.

One important question which arises is how right whales were able to cope with interannual and decadal-scale environmental variability before commercial whaling began, when the population was much higher and presumably closer to carrying capacity. Zooplankton concentrations sufficiently dense to support right whale feeding must have existed in many portions of the range from New England to Labrador. Assuming that the overall abundance of appropriate zooplankton prey is not drastically lower today, why then have right whales not re-colonised the northernmost portions of their historic range? An understanding of their strategy for locating feeding grounds might help to answer this question and to address the related issue of the long-term absence of any substantial recovery of the population. The hypothesis presented here is that:

(1) The surviving western North Atlantic population is a remnant of the historic stock which represents only the southern periphery of the original range. One should expect that the quality of the habitat on the periphery of any species' range would be lower than at the core of the range.

(2) Prey availability in the current range has probably always fluctuated with natural environmental variability. This would lead to alternating periods of prey abundance and energy limitation.
(3) Genetic studies indicate that the population has been small for hundreds of years (IWC, 2001). The combination of intervals of prey limitation, leading to increased mortality and/or reduced fecundity, with continued anthropogenic mortality has maintained the population at a very small size since the original reduction by Basque whaling. Mortality at first was directed and opportunistic killing by whalers, but presently whales are killed by ship strikes and entanglement in fishing gear (Kraus, 1990; Kenney and Kraus, 1993; Waring et al., 1999; Knowlton and Kraus, 2001).

(4) The population has simply never re-occupied the original core of its range. Given the evidence for maternally-directed habitat fidelity in North Atlantic right whales, one might predict that it could take a very long time to re-colonise habitats from which they had been extirpated.

It would be very interesting to do some fine-scale zooplankton sampling in the waters off Newfoundland and Labrador where the Basque fishery was prosecuted to learn whether high-density copepod patches capable of supporting right whales can be found there, as well as to compare zooplankton densities to those measured in current right whale feeding grounds. If the prey resource exists, and if management efforts can be successful at reducing or eliminating anthropogenic sources of mortality, it might be expected that some individuals would eventually re-occupy the northern portion of the range. Right whales have been occasionally observed as far north as Iceland and Norway in the last two decades (e.g. Knowlton et al., 1992; IWC, 2001). Interestingly, while the 1999 sighting in Norway was an adult male (IWC, 2001), of nine individuals photo-identified as of 1997 from northern areas (Gulf of St. Lawrence, Newfoundland, Labrador and Iceland), seven have been adult females, one was of unknown age and sex, and one was a male calf accompanying its mother (unpublished North Atlantic Right Whale Consortium photo-identification catalogue data). The best hope for the long-term recovery of western North Atlantic right whales may be those females taking their calves on 'the tour' of the foraging grounds, some day leading to re-occupation of the historic right whale habitat off eastern Canada.

\section{ACKNOWLEDGEMENTS}

This paper originated as a poster by the same three authors at the Eleventh Biennial Conference on the Biology of Marine Mammals in Orlando, Florida in December 1995, just four months after Howard Winn's death. His authorship here is not honorary, but recognises his input in creating or developing many of the hypotheses we have presented. Many of the ideas originated during long, often late-evening, discussions driven by scientific curiosity, camaraderie, and Howard's creative imagination (and sometimes rum). We are very grateful to all of our colleagues who have contributed ideas over the years, but will willingly accept full blame for any of them. In truth, it is often difficult to recall who may have been first to get up the courage to publicly voice any particular outrageous hypothesis. We are grateful to all of the many individuals over the years who have contributed their efforts to the right whale research programme, and to the two anonymous referees and Greg Donovan whose suggestions helped us to improve and clarify our ideas in this paper. In recognition of their 
willingness to freely speculate and stir the rest of us to productive research, we would like to dedicate this paper to the memories of Howard Winn and Ken Norris.

\section{REFERENCES}

Aguilar, A. 1986. A review of old Basque whaling and its effect on the right whales (Eubalaena glacialis) of the North Atlantic. Rep. int. Whal. Commn (special issue) 10:191-9.

Anderson, H.T. 1969. The Biology of Marine Mammals. Academic Press, New York. xii+511pp.

Baker, C.S., Herman, L.M., Perry, A., Lawton, W.S., Straley, J.M., Wolman, A.A., Kaufman, G.D., Winn, H.E., Hall, J.D., Reinke, J.M. and Ostman, J. 1986. Migratory movement and population structure of humpback whales, Megaptera novaeangliae, in the central and eastern North Pacific. Mar. Ecol. Prog. Ser. 31:105-19.

Baker, C.S., Palumbi, S.R., Lambertsen, R.H., Weinrich, M.T., Calambokidis, J. and O'Brien, S.J. 1990. Influence of seasonal migration on geographic distribution of mitochondrial DNA haplotypes in humpback whales. Nature, Lond. 344(6263):238-40.

Beardsley, R.C., Epstein, A.W., Chen, C., Wishner, K.F., Macaulay, M.C. and Kenney, R.D. 1996. Spatial variability in zooplankton abundance near feeding right whales in the Great South Channel. Deep-Sea Res. II 43(7-8):1,601-625.

Berta, A. and Sumich, J.L. 1999. Marine Mammals: Evolutionary Biology. Academic Press, San Diego, CA. xiii+494pp.

Berthold, P. 1996. Control of Bird Migration. Chapman \& Hall, London. ix $+355 \mathrm{pp}$.

Best, P.B. and Underhill, L.G. 1990. Estimating population size in southern right whales (Eubalaena australis) using naturally marked animals. Rep. int. Whal. Commn (special issue) 12:183-9.

Bigelow, H.B. 1926. Plankton of the offshore waters of the Gulf of Maine. Bull. Bur. Fish. Wash. 40(II):1-509.

Bovet, J. 1992. Mammals. p.321-61. In: F. Papi (ed.) Animal Homing. Chapman \& Hall, London. xii+390pp.

Brodie, P.F., Sameoto, D.D. and Sheldon, R.W. 1978. Population densities of euphausiids off Nova Scotia as indicated by net samples, whale stomach contents, and sonar. Limnol. Oceanogr. 23(6):1,264-267.

Brown, C.W. and Winn, H.E. 1989. Relationship between the distribution pattern of right whales, Eubalaena glacialis, and satellite-derived sea surface thermal structure in the Great South Channel. Cont. Shelf Res. 9(3):247-60.

Brown, M.W., Brault, S., Hamilton, P.K, Kenney, R.D., Knowlton, A.R., Marx, K., Mayo, C.A., Slay, C.K. and Kraus, S.D. 2001. Sighting heterogeneity of right whales in the western North Atlantic, 1980-1992. J. Cetacean Res. Manage. (special issue) 2:245-250.

Carr, A. 1980. Some problems of sea turtle ecology. Am. Zool. 20:489-98

Carr, A. 1982. Notes on the behavioural ecology of sea turtles. pp. 19-26. In: K.A. Bjorndahl (ed.) Biology and Conservation of Sea Turtles. Smithsonian Institution Press, Washington, DC. 583pp.

Carr, A. 1987. New perspectives on the pelagic stage of sea turtle development. Conserv. Biol. 1:103-21.

Caswell, H., Fujiwara, M. and Brault, S. 1999. Declining survival probability threatens the North Atlantic right whale. Proc. Natl Acad. Sci. USA 96(6):3,308-13.

CETAP. 1982. A Characterization of Marine Mammals and Turtles in the Mid- and North Atlantic Areas of the US Outer Continental Shelf. Report to the US Bureau of Land Management, Washington DC, Contract no. AA551-CT8-48. 586pp.

Chen, C., Beardsley, R.C. and Limeburner, R. 1995a. Variability of currents in late spring in the northern Great South Channel. Cont. Shelf Res. 15(4-5):451-73.

Chen, C., Beardsley, R.C. and Limeburner, R. 1995b. Variability of water properties in late spring in the northern Great South Channel. Cont. Shelf Res. 15(4-5):415-31.

Clapham, P.J. and Mayo, C.A. 1990. Reproduction of humpback whales (Megaptera novaeangliae) observed in the Gulf of Maine. Rep. int. Whal. Commn (special issue) 12:171-5.

Clapham, P.J., Baraff, L.S., Carlson, C.A., Christian, M.A., Mattila, D.K., Mayo, C.A., Murphy, M.A. and Pittman, S. 1993. Seasonal occurrence and annual return of humpback whales, Megaptera novaeangliae, in the southern Gulf of Maine. Can. J. Zool. 71(2):440-3.

Dittman, A.H. and Quinn, T.P. 1996. Homing in Pacific salmon. J. Exp. Biol. 199:83-91.

Ellison, W.T., Clark, C.W. and Bishop, G.C. 1987. Potential use of surface reverberation by bowhead whales, Balaena mysticetus, in under-ice navigation: preliminary considerations. Rep. int. Whal. Commn 37:329-32.
Fuller, M., Goree, W.S. and Goodman, W.L. 1985. An introduction to the use of SQUID magnetometers in biomagnetism. p. 103-51. In: J.L. Kirschvink, D.S. Jones and B.J. MacFadden (eds.) Magnetite Biomineralization and Magnetoreception in Organisms: A New Biomagnetism. Plenum Press, New York. 704pp.

Gaskin, D.E. 1987. Updated status of the right whale, Eubalaena glacialis, in Canada. Can. Field-Nat. 101(2):295-309.

Gaskin, D.E. 1991. An update on the status of the right whale, Eubalaena glacialis, in Canada. Can. Field-Nat. 105(2):198-205.

Gerrits, N.M. and Kastelein, R.A. 1990. A potential neural substrate for geomagnetic sensitivity in cetaceans. p. 31-8. In: J.A. Thomas and R.A. Kastelein (eds.) Sensory Abilities of Cetaceans: Laboratory and Field Evidence. Plenum Press, New York. xiii+710pp.

Goodyear, J.D. 1993. A sonic/radio tag for monitoring dive depths and underwater movements of whales. J. Wildl. Manage. 57(3):503-13.

Gross, M.G. 1996. Oceanography: A View of the Earth. 7th Edn. Prentice-Hall, Upper Saddle River, NJ. xiii+472pp.

Hain, J.H.W., Ellis, S.L., Kenney, R.D., Clapham, P.J., Gray, B.K., Weinrich, M.T. and Babb, I.G. 1995. Apparent bottom feeding by humpback whales on Stellwagen Bank. Mar. Mammal Sci. 11(4):464-79.

Hamilton, P.K. and Mayo, C.A. 1990. Population characteristics of right whales (Eubalaena glacialis) observed in Cape Cod and Massachusetts Bays, 1978-1986. Rep. int. Whal. Commn (special issue) $12: 203-8$.

Hamner, W.H. 1988. The 'lost year' of the sea turtle. Trends Ecol. Evol. 3:116-8.

International Whaling Commission. 2001. Report of the Workshop on Status and Trends of Western North Atlantic Right Whales. J. Cetacean Res. Manage. (special issue) 2:61-87.

Kalmijn, A.J. 1982. Electric and magnetic detection in elasmobranch fishes. Science 218:916-8.

Kenney, R.D. 1998. Global climate change and whales: western North Atlantic right whale calving rate correlates with the Southern Oscillation Index. Paper SC/M98/RW29 presented to the IWC Special Meeting of the Scientific Committee towards a Comprehensive Assessment of Right Whales Worldwide, 16-25 March, Cape Town, South Africa (unpublished). [Available from the Office of this Journal].

Kenney, R.D. 2001. Anomalous 1992 spring and summer right whale (Balaena glacialis) distributions in the Gulf of Maine. J. Cetacean Res. Manage. (special issue) 2:209-223.

Kenney, R.D. and Kraus, S. 1993. Right whale mortality - a correction and update. Mar. Mammal Sci. 9(4):445-6.

Kenney, R.D., Hyman, M.A.M., Owen, R.E., Scott, G.P. and Winn, H.E. 1986. Estimation of prey densities required by western North Atlantic right whales. Mar. Mammal Sci. 2(1):1-13.

Kenney, R.D., Winn, H.E. and Macaulay, M.C. 1995. Cetaceans in the Great South Channel, 1979-1989: Right whale (Eubalaena glacialis). Cont. Shelf Res. 15(4-5):385-414.

Ketten, D.R. 1991. The cetacean ear: form, frequency, and evolution. pp. 53-75. In: J.A. Thomas, R.A. Kastelein and A.Y. Supin (eds.) Marine Mammal Sensory Systems. Plenum Press, New York. xiv+773pp.

Kirschvink, J.L. 1990. Geomagnetic sensitivity in cetaceans: an update with live stranding records in the United States. pp. 639-49. In: J.A. Thomas and R.A. Kastelein (eds.) Sensory Abilities of Cetaceans: Laboratory and Field Evidence. Plenum Press, New York and London. xiii+710pp.

Kirschvink, J.L., Dizon, A.E. and Westphal, J.E. 1986. Evidence from strandings for geomagnetic sensitivity in cetaceans. J. Exp. Biol. 120:1-24.

Klinowska, M. 1985. Cetacean live stranding sites relate to geomagnetic topography. Aquat. Mamm. 1:27-32.

Klinowska, M. 1990 . Geomagnetic orientation in cetaceans: behavioural evidence. pp. 651-63. In: J.A. Thomas and R.A. Kastelein (eds.) Sensory Abilities of Cetaceans: Laboratory and Field Evidence. Plenum Press, New York and London. xiii+710pp.

Knowlton, A.R. 1997. The feasibility of regulating vessel traffic to protect North Atlantic right whales (Eubalaena glacialis). Masters Thesis, University of Rhode Island, Kingston, RI. 185pp.

Knowlton, A. and Kraus, S. 2001. Mortality and serious injury of northern right whales (Eubalaena glacialis) in the western North Atlantic Ocean. J. Cetacean Res. Manage. (special issue) 2:193-207.

Knowlton, A.R., Sigurjónsson, J., Ciano, J.N. and Kraus, S.D. 1992. Long-distance movements of North Atlantic right whales (Eubalaena glacialis). Mar. Mammal Sci. 8(4):397-405.

Knowlton, A.R., Kraus, S.D. and Kenney, R.D. 1994. Reproduction in North Atlantic right whales (Eubalaena glacialis). Can. J. Zool. 72(7):1,297-305. 
Kraus, S.D. 1990. Rates and potential causes of mortality in North Atlantic right whales (Eubalaena glacialis). Mar. Mammal Sci. 6(4):278-91.

Kraus, S.D. and Kenney, R.D. 1991. Information on right whales (Eubalaena glacialis) in three proposed critical habitats in United States waters of the western North Atlantic Ocean. Report to Marine Mammal Commission, Washington, DC, Contract Nos T-75133740 and T-75133753. 65pp.

Kraus, S.D., Crone, M.J. and Knowlton, A.R. 1988. The North Atlantic right whale. pp. 684-98. In: W.J. Chandler (ed.) Audubon Wildlife Report 1988/1989. Academic Press, New York. 817pp.

Kraus, S.D., Kenney, R.D., Knowlton, A.R. and Ciano, J.N. 1993. Endangered right whales of southwestern North Atlantic. Final Report, Minerals Management Service Contract No. 14-35-0001-30486. Edgerton Research Laboratory, New England Aquarium, Boston, MA.

Kraus, S., Hamilton, P., Kenney, R., Knowlton, A. and Slay, C. 2001. Reproductive parameters of the North Atlantic right whale. $J$. Cetacean Res. Manage. (special issue) 2:231-236.

Kuznetzov, V.B. 1990. Chemical sense of dolphins: quasi-olfaction. pp. 481-503. In: J.A. Thomas and R.A. Kastelein (eds.) Sensory Abilities of Cetaceans, Laboratory and Field Evidence. Plenum Press, New York and London. 710pp.

Ling, J.K. 1977. Vibrissae of marine mammals. pp. 387-415. In: R.J. Harrison (ed.) Functional Anatomy of Marine Mammals. Vol. 3. Academic Press, London. $\mathrm{x}+428 \mathrm{pp}$.

Lohmann, K.J. and Lohmann, C.M.F. 1996. Orientation and open-sea navigation in sea turtles. J. Exp. Biol. 199:73-81.

Macaulay, M.C., Wishner, K.F. and Daly, K.L. 1995. Acoustic scattering from zooplankton and micronekton in relation to a whale feeding site near Georges Bank and Cape Cod. Cont. Shelf Res. 15(4-5):509-37.

Malik, S., Brown, M.W., Kraus, S.D., Knowlton, A.R., Hamilton, P.K. and White, B.N. 1999. Assessment of mitochondrial DNA structuring and nursery use in the North Atlantic right whale (Eubalaena glacialis). Can. J. Zool. 77(81):1217-22.

Malme, C.I. 1995. Sound propagation. pp. 59-86. In: W.J. Richardson, C.R. Greene, C.I. Malme and D.H. Thomson (eds.) Marine Mammals and Noise. Academic Press, San Diego, CA. xvi+576pp.

Mate, B.R., Nieukirk, S.L. and Kraus, S.D. 1997. Satellite-monitored movements of the northern right whale. J. Wildl. Manage. 61(4):1393-405.

Matthews, L.H. 1938. Notes on the southern right whale, Eubalaena australis. Discovery Rep. 17:169-82.

Mayo, C.A. and Goldman, L. 1992. Right whale foraging and the plankton resources in Cape Cod and Massachusetts Bays. pp. 43-4 In: J. Hain (ed.) The Right Whale in the Western North Atlantic: A Science and Management Workshop. NEFSC Ref. Doc. 92-05. National Marine Fisheries Service, Northeast Fisheries Science Center, Conservation and Utilization Division, Woods Hole, MA. ix+88pp.

Mayo, C.A. and Marx, M.K. 1990. Surface foraging behaviour of the North Atlantic right whale, Eubalaena glacialis, and associated zooplankton characteristics. Can. J. Zool. 68:2,214-0.

Mayo, C.A., Mattila, D.K., Pittman, S. and Baraff, L.S. 1988. Abundance, distribution and habitat use of large whales in the southern Gulf of Maine. Final Report to the National Marine Fisheries Service, Northeast Fisheries Science Center contract 50-EANF-5-00130. NMFS, NEFSC, Woods Hole, MA 02543. 178 pp.

Moore, M., Miller, C.A., Morss, M.S., Arthur, R., Lange, W.A. Prada, K.G. Marx, M.K. and Frey, E.A. 2001. Ultrasonic measurement of blubber thickness in right whales. J. Cetacean Res. Manage. (special issue) $2: 301-309$.

Murison, L.D. and Gaskin, D.E. 1989. The distribution of right whales and zooplankton in the Bay of Fundy, Canada. Can. J. Zool. 67(6): 1,411-20

Nachtigall, P.E. 1986. Vision, audition, and chemoreception in dolphins and other marine mammals. pp. 79-113. In: R.J. Schusterman, J.A. Thomas and F.G. Wood (eds.) Dolphin Cognition and Behavior: A Comparative Approach. Lawrence Erlbaum Assoc., Hillsdale, NJ. xv+393pp.

Nemoto, T. 1970. Feeding pattern of baleen whales in the ocean. pp. 241-52. In: J.H. Steele (ed.) Marine Food Chains. Oliver and Boyd, Edinburgh. 552pp.

Norris, K.S. 1967. Some observations on the migration and orientation of marine mammals. pp. 101-25. In: R.M. Storm (ed.) Animal Orientation and Navigation. Proceedings of the Twenty-Seventh Annual Biology Colloquium. Oregon State University Press, Corvallis, OR. ix+134pp.
Omura, H., Ohsumi, S., Nemoto, R., Nasu, K. and Kasuya, T. 1969. Black right whales in the North Pacific. Sci. Rep. Whales Res. Inst., Tokyo 21:1-78.

Payne, P.M., Wiley, D.N., Young, S.B., Pittman, S., Clapham, P.J. and Jossi, J.W. 1990. Recent fluctuations in the abundance of baleen whales in the southern Gulf of Maine in relation to changes in selected prey. Fish. Bull. 88:687-96.

Payne, R. 1976. At home with right whales. Natl. Geogr. 149(3):322-39.

Payne, R., Rowntree, V., Perkins, J.S., Cooke, J.G. and Lankester, K. 1990. Population size, trends and reproductive parameters of right whales (Eubalaena australis) off Peninsula Valdes, Argentina. Rep. int. Whal. Commn (special issue) 12:271-8.

Pike, G.C. 1962. Migration and feeding of the gray whale (Eschrichtius gibbosus). J. Fish. Res. Bd Can. 19(5):815-38.

Pilleri, G. and Gihr, M. 1970. The central nervous system of the mysticete and odontocete whales. pp. 89-128. In: G. Pilleri (ed.) Vol. 2. Investigations on Cetacea. Institute of Brain Anatomy, University of Berne, Berne. 296pp.

Pilleri, G. and Knuckey, J. 1969. Behaviour patterns of some Delphinidae observed in the western Mediterranean. Z. Tierpsychol. 26:48-72.

Pryor, K. 1990. Concluding remarks on vision, tactition, and chemoreception. pp. 561-9. In: J.A. Thomas and R.A. Kastelein (eds.) Sensory Abilities of Cetaceans: Laboratory and Field Evidence. Plenum Press, New York. xiii+710pp.

Quinn, T.P. and Dittman, A.H. 1992. Fishes. pp. 145-211. In: F. Papi (ed.) Animal Homing. Chapman \& Hall, London. xii+390pp.

Reeves, R.R. and Mitchell, E. 1986. The Long Island, New York, right whale fishery: 1650-1924. Rep. int. Whal. Commn (special issue) 10:201-20.

Reeves, R.R. and Mitchell, E. 1988. History of whaling in and near North Carolina. NOAA Technical Report NMFS-65. National Marine Fisheries Service, US Department of Commerce, Seattle, WA. iii+28pp.

Reeves, R.R., Breiwick, J.M. and Mitchell, E. 1992. Pre-exploitation abundance of right whales off the eastern United States. pp. 5-7. In: J. Hain (ed.) The Right Whale in the Western North Atlantic: A Science and Management Workshop. NEFSC Ref. Doc. 92-05. National Marine Fisheries Service, Northeast Fisheries Science Center, Conservation and Utilization Division, Woods Hole, MA. ix+88pp.

Richardson, W.J. 1995. Marine mammal hearing. pp. 205-40. In: W.J. Richardson, C.R. Greene, C.I. Malme and D.H. Thomson (eds.) Marine Mammals and Noise. Academic Press, San Diego. $\mathrm{xvi}+576$.

Schaeff, C.M., Kraus, S.D., Brown, M.W. and White, B.N. 1993. Assessment of the population structure of western North Atlantic right whales (Eubalaena glacialis) based on sighting and mtDNA data. Can. J. Zool. 71(2):339-45.

Sinsch, U. 1992. Amphibians. pp. 213-33. In: F. Papi (ed.) Animal Honing. Chapman \& Hall, London. xii+390pp.

Sorensen, P.W. 1986. Origins of the freshwater attractant(s) of migrating elvers of the American eel, Anguilla rostrata. Environ. Biol. Fish. 17:185-200.

Tomilin, A.G. 1957. Zveri SSSR i Prilezhasfchikh Stran. Zveri Vostochnoi Evropy i Severnoi Azii. Izdatel'stvo Akademi Nauk SSSR, Moscow. 756pp. [Translated in 1967 as Mammals of the USSR and Adjacent Countries. Mammals of Eastern Europe and Adjacent Countries. Vol. IX. Cetacea by the Israel Program for Scientific Translations, Jerusalem, 717pp.][In Russian].

Walker, M.M. 1984. Learned magnetic field discrimination in yellow fin tuna, Thunnus albacares. J. Comp. Physiol. A. Sens. Neural Behav. Physiol. 155:673-9.

Walker, M.M., Kirschvink, J.L., Ahmed, G. and Dizon, A.E. 1992. Evidence that fin whales respond to the geomagnetic field during migration. J. Exp. Biol. 171:67-78.

Waring, G.T., Palka, D.L., Clapham, P.J., Swartz, S., Rossman, M.C., Cole, T.V.N., Hansen, L.J., Bisack, K.D., Mullin, K.D., Wells, R.S., Odell, D.K. and Barros, N.B. 1999. NOAA Technical Memorandum NMFS-NE-153. US Atlantic and Gulf of Mexico marine mammal stock assessments, 1999. National Marine Fisheries Service, US Department of Commerce, Woods Hole, MA. 196pp.

Wartzok, D. and Ketten, D.R. 1999. Marine mammal sensory systems. pp. 117-75. In: J.E. Reynolds and S.A. Rommel (eds.) Biology of Marine Mammals. Smithsonian Institution Press, Washington, DC. viii+578pp.

Watkins, W.A. and Schevill, W.E. 1976. Right whale feeding and baleen rattle. J. Mammal. 57(1):58-66.

Watkins, W.A. and Schevill, W.E. 1979. Aerial observations of feeding behavior in four baleen whales: Eubalaena glacialis, Balaenoptera 
borealis, Megaptera novaeangliae and Balaenoptera physalus. J. Mammal. 60(1):155-63.

Weinrich, M.T., Kenney, R.D. and Hamilton, P.K. 2000. Right whales (Eubalaena glacialis) on Jeffreys Ledge: A habitat of unrecognized importance? Mar. Mammal Sci. 16:326-7.

Wenzel, B.M. 1980. Chemoreception in seabirds. pp. 41-67. In: J. Burger, B.L. Olla and H.E. Winn (eds.) Behavior of Marine Animals: Current Perspectives in Research. Volume 4: Marine Birds. Plenum Press, New York, NY. xvii+515pp.

Wiltschko, W. and Wiltschko, R. 1996. Magnetic orientation in birds. J. Exp. Biol. 199:29-38.

Winn, H.E. and Price, C.A. 1982. A model (scheme) of the annual activities of the right whale. Appendix A. In: CETAP (ed.) A Characterization of Marine Mammals and Turtles in the Mid-and North-Atlantic Areas of the US Outer Continental Shelf, Final Report. US Dept. of the Interior, Bureau of Land Management, Washington, DC. Contract No. AA551-CT8-48. (NTIS no. PB83215 855). 586pp.

Winn, H.E. and Price, C.A. 1983. A model (scheme) of the annual activities of the right whale. Paper SC/35/RW29 presented to the
IWC Symposium and Workshop on the status of Right Whales, 15-23 June 1983, Boston, Massachusetts (unpublished). [Available from the Office of this Journal].

Winn, H.E., Price, C.A. and Sorensen, P.W. 1986. The distributional biology of the right whale (Eubalaena glacialis) in the western North Atlantic. Rep. int. Whal. Commn (special issue) 10:129-38.

Winn, H.E., Goodyear, J.D., Kenney, R.D. and Petricig, R.O. 1995. Dive patterns of tagged right whales in the Great South Channel. Cont. Shelf Res. 15(4-5):593-611.

Wishner, K., Durbin, E., Durbin, A., MacAulay, M., Winn, H. and Kenney, R. 1988. Copepod patches and right whales in the Great South Channel off New England. Bull. Mar. Sci. 43(3):825-44.

Wishner, K.F., Schoenherr, J.R., Beardsley, R. and Chen, C. 1995. Abundance, distribution and population structure of the copepod Calanus finmarchicus in a springtime right whale feeding area in the southwestern Gulf of Maine. Cont. Shelf Res. 15(4-5):475-507.

Zoeger, J., Dunn, J.R. and Fuller, M. 1981. Magnetic material in the head of the common Pacific dolphin. Science 213:892-4. 